\title{
国内トピックス
}

\section{食品に全成分表示を義務付けか一 厚生省郎談会の最終報告}

厚生省の食と健康を考える留談会（厚相の諮問機関, 会長伊東信行名古屋市立大学学長) は, 栄養価のある食 品において全成分表示を義務づけるべきとの最終報告を 平成 6 年内に出す。

米国ではすでに 6 年 5 月, USDA (米農務省), $\mathrm{FD}$ A（米食品医薬品局）によって加工食品の全成分表示が 義務付けられたが, わが国では, メーカーが限られた成 分だけを強調したり, 表示にあいまいさがあるとの指摘 が従来からあった。全成分表示が義務付けられれば, 多 数のメーカーは表示の大幅な手直しを余儀なくされる。 その半面消費者に対する新しい商品請求ポイントにもな り得る。

厚生省は, この最終報告を受けて食品衛生法, 栄養改 善法二法の改正案を次期通常国会に提出, 表示の規格基 準化を目指す（日刊工業，94，11，3）。

\section{新鮮な香りを急速冷凍で保持する スジャータレギュラーコーヒー}

名古屋製酪(烌では焙煎即急速冷凍製法による， ス ジャータ IFCレギュラーコーヒーを平成 4 年度より発 売し，売上を伸ばしてきた。

新鮮なコーヒーはドリップの際, コーヒー粉末に熱湯 を注ぐと, 粉末全体が大きく膨張し盛り上がるが, これ はコーヒー豆に含まれる香りのガス（アロマ）に起因す ると考えられる。同社はコーヒ一の香りの基である香気 性ガスを長くコーヒーの粉の中に閉じ込めうる冷凍製法 を開発した。

焙煎後ただちに急速冷凍された焙煎豆を，そのままグ ラインドし, 香りの基である香気性を封じ込める。急速 冷凍法で製造された製品は, 保管・流通・販売も, 冷凍 または冷蔵チャネル, チルド売場を利用している。

この製法は現在アメリカと台湾の特許認可を得てい る。レギュラーコーヒーはこれまで, 焙煎後の芳香の散 逸による風味の劣化をいかに防ぐか, がメーカーと使用 者双方の大きな課題であったが, 名古屋製酪㑣)開発技
術はこの障壁を乗り超えたことになる。スジャータ IF Cレギュラーコーヒーはロイヤル, スペシャル, マイル ドの各種パック $200 \mathrm{~g}$ 小売価格 200 円, ドリップタイプ 8 $\mathrm{g} \times 5$ 杯分が150円。

同社では当製品群の 6 年度売上高を 15 億円と見込んで いる（名古屋製酪㑣談，94．12．10）。

\section{急成長の冷凍米飯市場, 夏季の猛暑で停滞, 価格の見直しへ}

冷凍米飯は, 日本冷凍食品協会 (会長 : (懒)ニチレイ会 長・金田幸三氏）の調べでは，平成元年 $48,640 \mathrm{t}$ の生産 量が平成 5 年には $119,070 \mathrm{t}$ と 4 年間で2. 4 倍以上の急成 長を遂げた製品分野である。平成 5 年の「コメ騒動」時 には輸入米の利用技術が進み，また各社の値上げにもか かわらず需要の強さは供給力を上回った。しかし平成 6 年中盤から, コメの豊作, 新米の出回りや, 夏季の猛暑 などで, 冷食米飯は停滞気味となった。

このような環境変化のもと, 各社とも国産米に再び切 り替えた新商品の発表や，二チロをはじめとする製品価 格の值下げを行うなど，これに対応している。また加卜 吉のように新潟県に工場を新設し，米飯の製造を開始す るなど積極的な動きを示すメーカーもある。

いずれにしても従来好調裡に進展してきた米飯冷食市 場が, 製造出荷額587億円を超えたところで最初の曲が り角にさしかかったものであるが，長期的には消費需要 の成長と品目の多彩化に支えられ，まだ伸びる見通しで ある（日本食糧，6，11．16）。

\section{猛暑で急伸したアイスクリーム市場}

平成 6 年夏の猛暑はアイスクリーム業界にとってまさ に神風であった。このところアイスクリームの販売量 は， 90年の 91 万 $\mathrm{k}$ をピークに年々下降し，冷夏の 93 年 には80.7万k にに落ちていた。「100のマーケティングよ り今日の天気」を立証したのが94年夏の猛暑であった。 同年 6 月の家計調查によれば全国平均 1 世帯あたりのア イスクリーム支出金額は前年同月比 $108.4 \%$ で，地域別 では北陸, 東海の各127\%, 東京都区部の $119 \%$ が特に目 立った。 
さらに 7 月に入り, 東京の真夏日は 25 日（93年は 5 日), 大阪では31日（同，14日）で毎日が真夏日，8月 も東京が27日（同，10日），大阪が31日（同，20日）と 2 ケ月連続連日が真夏日の, 史上最高記録となった。

7 月の猛暑でアイスクリームが飛ぶように売れたため 各社とも供給不安が表面化したくらいである。

94年 7 月の各社の売上高前年同月比は，雪印乳業 154 $\%$, 明治乳業160\%, 森永乳業150\%, カネボウフーズ 131\%，江崎グリコ130\%，ハーゲンダッツ146\%であっ た。 4 9 月の上半期では業界平均で $125 \%$ 以上であっ たようだ（酒類食品統計月報，94．6）。

\section{卵白使いヨーグルト タニショウ果汁研究所}

タニショウ果汁研究所（熊本市, 谷口健二社長）は原 料に卵白を使ったヨーグルトを商品化，94年12月から スーパーや外食産業向けに OEM（相手先ブランドによ る生産）供給を始めた。乳酸菌の含有量が $1 \mathrm{~g}$ 当たり 6 億 3 千万個之, 従来品より $20 \%$ も多いうえ, 口当りが良 い。商品名は「卵白ヨーグルト」。新製品は生乳と卵白 を半分ずつ混ぜてから発酵させる。その際ある種の不活 性ガスを使い，混合直前に卵白を泡立てるなどの技術を 開発した。その結果ババロア風のケーキのようなヨーグ ルトに仕上っている。

卵白を使ったことから，生産コス卜も比較的抑えられ た。マヨネーズやケーキ向けの需要が多い卵黄に比べ, 用途の少ない卵白は余り気味で相場も安い。

平成 6 年12月までに九州一円に展開している洋菓子店 の「エブリディ」や「サブマリン」など138店舗で試食 販売を始めている。固型と液状の 2 種類がある。販売目 標は月間15万個（日経産業，94，11．11）。

\section{冷凍雑煮一レンジで 2 分, 餅も溶けず}

岩手阿部製粉（岩手県石鳥谷町，社長阿部淳也氏）は 電子レンジで 2 分加熱すれば, すぐに食べられる冷凍雑 煮を開発した。ニンジン, ゴボウなどの野菜のほか, 餅 が入っている。これまで，餅は電子レンジで加熱すると 溶けてしまうため, 冷凍雑者の開発は難しいとされてい た。

餅は無添加原料を用い，独自の保管，加工技術を導入 した結果，粘り強いものに仕上げた。また同社は野菜に 付着する土裹菌を滅菌し，無害にする技術も持ってお り, 野菜の長期冷凍保存が可能になった。

価格は 1 食分 250 円， 2 食 1 パックとし, 同社製品の フランチャイズチェーンショップ「北上京チェーン」や 生協などで販売し，94年末からの冬期に50万食の売上を
見込む（日経産業，94．10．17）。

\section{カレーライスをコボリが冷凍品に}

コメ集荷, 小売りのコボリ（栃木県芳賀町, 社長小堀 好之氏）は冷凍のカレーライスを商品化した。カレーと ライスを一つの容器に盛って冷凍する之解凍時間にずれ が生じるために製品化が難しかった。新製品は冷凍方法 や容器への工夫などにより，風味を損わず均一に解凍で きるのが特徵。

炊飯方法や瞬間冷凍技術により, 解凍後もライスはぱ さつかず, 炊きたての風味之食感が変らない。

なお同社は「解凍寿司」の名称で, 冷凍の握りずしや 巻き寿司，いなり寿司をすでに商品化している。これら は95年 4 月から日本アジア航空が機内食として日台路線 の全便に採用するなど需要が拡大している（日経産業, 10. 26)。

\section{アサヒビール飲料, 全国にチルド飲料}

アサヒビール飲料（東京都墨田区，佐野主税社長）は 要冷蔵（チルド）の紙パック入り飲料事業を強化する。

チルド紙パック入りは缶入りよりも熱殺菌する度合い が小さく, 果汁などは本物に近い味になるので, 需要拡 大が見込めると見ている。同社はチルド製品の売り上げ を96年度には，94年度の 2 倍強の 70 億円に引き上げる計 画。

同社のチルド紙パック飲料の新製品は「バヤリース マスクメロン」。高級感のあるマスクメロンの果汁を初 めて5.5\%加えた。さらに $500 \mathrm{~m} \ell の$ 価格を 100 円に抑え た。知名度の高い「バヤリース」ブランドでは午や瓶入 りを含めて, はじめて $500 \mathrm{~m}$ 亿入りを 100 円にした戦略商 品である（日経，94，10．31）。

\section{日本リーバのアイス事業, 森永乳業に 再度販売を委託}

大手の多国籍食品企業が日本市場の参入に際し, もっ とも悩むのは物流問題である。日本リーバのアイスク リームは古くはマレーシア, シンガポール, タイ, 最近 では北京などを中心に中国にも進出している。多くは地 元の大手流通業者と提携し，そのルートに乗せて製品を 流通させる。

森乳は79年日本リーバ（東京渋谷, 赤岩覚社長）とア イスクリーム事業で提携し，83年から「ビエネッタ」と いう高級アイスクリームの製造, 販売を開始した。日本 リーバはその後更なる売上増を狙い，90年からマーケ ティング活動を自社で行っていた。しかし森永乳業ほよ゙ 
の販売網を持っていなかったため期待したほど売り上げ が伸びず，再び実績のある森乳の販売力を生かすことに したもの。森乳にとってもアイスクリームの品揃えと販 売量が増える利点が出る。

「ビエネッタ」はユニリーバ社の特許技術を用いた，
アイスクリームを複雑な重層構造にした高級品である。 森乳は独自の市場分析の結果を反映させ，仕様などを一 部変更した新製品を94年10月から販売している（日経産 業, 94.10.18)。

〔食品評論家・中小企業診断士 大和弥寿〕 